\title{
QUALITATIVE AND QUANTITATIVE PHYTOCHEMICAL ANALYSIS OF ENDOPHYTIC FUNGI (EF8; ASPERGILLUS SP.3) ISOLATED FROM BOERHAVIA DIFFUSA L., STEM.
}

\author{
DEEPENDRA THAKUR ${ }^{1}$, KAMANA SAHANI ${ }^{1,2 *}$ \\ ${ }^{1}$ Department of Microbiology, Bangalore University, Bengaluru, Karnataka, India, ${ }^{2}$ Department of Microbiology, Andhra University, \\ Visakhapatnam, Andhra Pradesh, India. Email: kmnsahani@gmail.com
}

Received: 25 July 2018, Revised and Accepted: 20 January 2019

\section{ABSTRACT}

Objective: The objective of the present investigation was to find phytochemical constituents of endophytic fungi Aspergillus sp.3 isolated from Boerhavia diffusa L. stem.

Methods: Both qualitative and quantitative phytochemical analysis was performed.

Results: In the present investigation, endophytic fungi was isolated from the medicinal plant $B$. diffusa L. The qualitative and quantitative phytochemical analysis was performed from the endophytic fungi Aspergillus sp.3 which showed the presence of phenol, flavonoids, alkaloids, steroids, and terpenoids, $11.66 \pm 0.577,17.66 \pm 0.577,1.746 \pm 0.0057,0.446 \pm 0.0057$, and $9.746 \pm 0.0057$ ( $\mu$ g of standard/mg of extract), respectively.

Conclusion: Hence, the endophytic fungi isolated from B. diffusa L. could be regarded as good sources of bioactive compounds for drug formulations.

Keywords: Phytochemical, Phenol, Flavonoids, Alkaloids, Endophytic fungi, Boerhavia diffusa L.

(C) 2019 The Authors. Published by Innovare Academic Sciences Pvt Ltd. This is an open access article under the CC BY license (http://creativecommons. org/licenses/by/4. 0/) DOI: http://dx.doi.org/10.22159/ajpcr.2019.v12i3.28242

\section{INTRODUCTION}

Boerhavia diffusa L. (Family Nyctaginaceae) is a herbal plant, which is common in tropics in both dry and rainy seasons. It is found in India, Nigeria, and many other countries. B. diffusa is used in traditional medicine for its anti-inflammatory, antibacterial, and cardiotonic properties [1]. It is used in the treatment of elephantiasis, night blindness, and corneal ulcers [2]. Conventionally, the plant has been evaluated for its hepatoprotective, anti-diabetic, diuretic, antiinflammatory, antibacterial, antiviral, and anticancer properties [3].

Endophytes are symbiotically associated microorganism of living plants potential sources of biologically active natural products in medical, agricultural, and industrial applications. They have been found in every plant species studied and it is approximated to be around a million or more endophytic fungi in nature. Therefore, there is an ample opportunity to unearth a novel and interesting endophytic microorganism with significant therapeutic efficacy [4]. Selection of appropriate higher plants study and isolation of microfloral components can be achieved by a superior understanding of the mechanism of endophytes existence and their interactions with the surroundings. This procedure may help in unrevealing the new natural product. However, the extent of utilization of the endophytic microorganism for food and health industries is still modest, compared to the ample number of useful microorganism [5].

Phytochemical and antioxidant activity of $B$. diffusa L. plants were studied [6] and their review by [7]. The objective of the present study was to isolate endophytic fungi from $B$. diffusa $L$. and to check their phytochemical constituents.

\section{METHODS}

Collection of plant material

Visakhapatnam (Location $17^{\circ} 40^{\prime} 48.32^{\prime \prime} \mathrm{N}, 83^{\circ} 12^{\prime} 5.8^{\prime \prime} \mathrm{E}$ ) is situated between the Eastern Ghats and the Bay of Bengal. The annual mean temperature ranges between $24.7^{\circ} \mathrm{C}$ and $30.6^{\circ} \mathrm{C}\left(76^{\circ} \mathrm{F}-87^{\circ} \mathrm{F}\right)$, with the maximum in the month of May and minimum in January; the minimum temperature ranges between $20^{\circ} \mathrm{C}$ and $27^{\circ} \mathrm{C}\left(68^{\circ} \mathrm{F}-81^{\circ} \mathrm{F}\right)$ and the average annual rainfall recorded is $1118.8 \mathrm{~mm}$. The plant was located on the campus of Andhra University. Healthy and mature plants of B. diffusa L. was collected from the campus, Andhra University. The sample was tagged and placed in a sterile polyethylene bag, brought to the laboratory and processed within $24 \mathrm{~h}$ of collection $[8,9]$. Fresh plant material was used for the isolation work to reduce the chance of contamination. Sample collection was done in January 2016 and the plant used in the study was authenticated by Prof. S. B. Padal (Botanist), Department of Botany, Andhra University, Visakhapatnam and the plant material was also deposited in Botany Department herbarium (AUV), Andhra University, Visakhapatnam with Voucher specimen numbers - 22,296.

\section{Isolation of endophytic fungi}

The sample was washed thoroughly in running tap water before processing. Stem samples were surface sterilized by dipping in $70 \%$ ethanol (v/v) for $1 \mathrm{~min}$ and $3.5 \% \mathrm{NaOCl}(\mathrm{v} / \mathrm{v})$ for $3 \mathrm{~min}$, rinsed thrice with sterile water and dried. Bits of $1.0 \mathrm{~cm} \times 1.0 \mathrm{~cm}$ size were excised with the help of a sterile blade. Two hundred segments of B. diffusa L. plant stem segments were placed on the water ager (16\%) (WA) medium supplemented with streptomycin (100 mg/l; Sigma, St. Louis, MO, USA) were used for the isolation of endophytic fungi. The Petri dishes were sealed using parafilm and the Petri dishes were incubated at $25^{\circ} \mathrm{C}-27^{\circ} \mathrm{C}$ till the mycelia start growing from the samples [10].

Secondary metabolite production of endophytic fungal isolate The endophytic fungus EF8, i.e., Aspergillus sp.3 was cultured in 1-1 Erlenmeyer flasks containing $500 \mathrm{ml}$ of optimized culture media (potato dextrose broth) under optimized parameters (pH:5.5-6.5, Temperature: $25^{\circ} \mathrm{C}-30^{\circ} \mathrm{C}$, Incubation days:8-9 days) under static conditions. The culture broth was filtered to separate the culture filtrate and mycelium. Culture filtrate was blended thoroughly and centrifuged at $4000 \mathrm{rpm}$ for $5 \mathrm{~min}$. Liquid supernatant was extracted with an equal volume of solvent thrice separately and was evaporated to dryness under reduced pressure at $50^{\circ} \mathrm{C}$ using rotary flash evaporator [11]. 
Qualitative phytochemical analysis [12-14]

\section{Alkaloids}

The endophytic fungal crude extract was evaporated to dryness in the boiling water bath. The residues were dissolved in $2 \mathrm{~N} \mathrm{HCl}$. The mixture was filtered and the filtrate was used for the following test:

- Wagner's test: Filtrate was treated with Wagner's reagent; formation of brown reddish precipitate indicates the presence of alkaloids

- Hager's test: Filtrate was treated with Hager's reagent; the presence of alkaloid was confirmed by the yellow color precipitate

- Flavonoids

- Alkaline reagent test: The endophytic fungal extract was treated with $10 \%$ ammonium hydroxide solution. Yellow fluorescence indicates the presence of flavonoids

- Shinoda test $(\mathrm{Mg} / \mathrm{HCl}$ or $\mathrm{Zn} / \mathrm{HCl}$ reduction test): In a test tube containing $0.5 \mathrm{ml}$ of endophytic fungal crude extract, 5-10 drops of diluted HCL and a small piece of zinc or magnesium were added, and the solution was boiled for few minutes. In the presence of flavonoid pink or dirty brown color was produced.

Phenol

- Ferric chloride test: The endophytic fungal extract was treated with $5 \%$ ferric chloride solution a dark green color indicates the presence of phenol

- Lead acetate test: The endophytic fungal extract was treated with $10 \%$ lead acetate a bulky white color indicates the presence of phenol.

Steroid

- Salkowski test: $0.5 \mathrm{ml}$ of endophytic fungal crude extract was mixed in $2 \mathrm{ml}$ of chloroform and sulphuric acid was added shaken well and allow standing for some time a reddish brown color at the interface indicates the presence of the steroidal ring

- Terpenoid

- The Libermann-Burchard test: To $1 \mathrm{ml}$ of the endophytic fungal crude extract with few drops of acetic acid and $1 \mathrm{ml}$ concentrated sulphuric acid gives deep red at the junction of 2 layers indicates the presence of terpenoids.

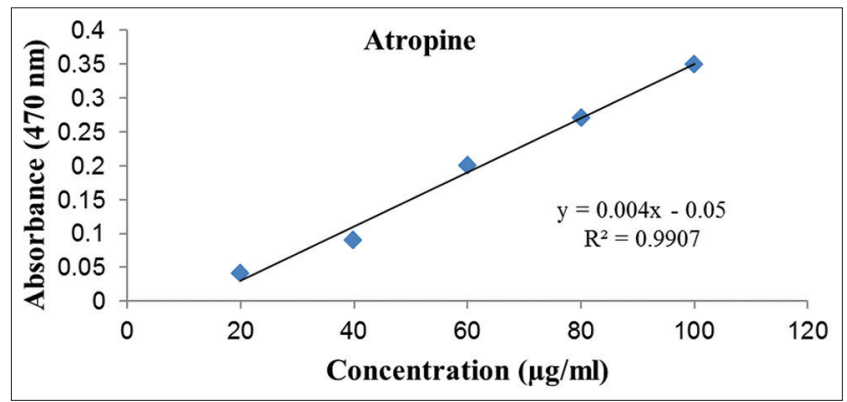

Figure 1: Calibration curve of alkaloid

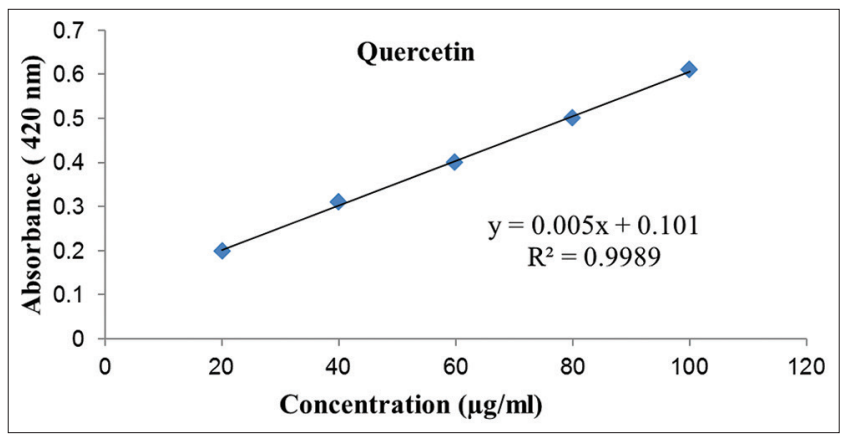

Figure 2: Calibration curve of flavonoids
Tannin

- Ferric chloride test: Endophytic fungal extract (1 ml) was taken to which few drops of $10 \%$ alcoholic ferric chloride was added bluish black color which disappears on the addition of little sulfuric acid was followed by formation of the yellowish brown precipitate.

\section{Amino acids and protein}

- Ninhydrin test: Test solution when boiled with $0.2 \%$ solution of Ninhydrin, would result in the formation of purple color suggesting the presence of free amino acids

- Biuret test: Test solution when treated with $10 \%$ sodium hydroxide solution andtwo drops of $0.1 \%$ copper sulfate solution and observed for the formation of violet-pink color which indicates the presence of protein

\section{Carbohydrate}

- Molisch test: Endophytic fungal extract was treated with two drops of alcoholic $\alpha$-naphthol solution in the test tube, and the mixture was shaken well and the few drops of concentrated sulfuric acid was added slowly along the sides of test tubes. A violet ring indicates the presence of carbohydrate.

\section{Quantitative phytochemical analysis}

\section{Estimation of total alkaloids}

Total alkaloid content was estimated by the method of $[15,16]$ with minor modification.

Briefly, endophytic fungal crude extract $(1 \mathrm{mg} / \mathrm{ml})$ was dissolved in $2 \mathrm{~N} \mathrm{HCl}$ and then filtered. $1 \mathrm{ml}$ of this solution was transferred to separatory funnel and washed with $10 \mathrm{ml}$ chloroform (three times). The $\mathrm{pH}$ of this solution was adjusted to neutral with $0.1 \mathrm{~N} \mathrm{NaOH}$. Then, $5 \mathrm{ml}$ of Bromocresol green solution and $5 \mathrm{ml}$ of phosphate buffer $\mathrm{pH} 7.4$ were added to this solution and the mixture was shaken properly and complex was extracted with 1, 2, 3, and $4 \mathrm{ml}$ chloroform by vigorous shaking, the extract was then collected in a $10 \mathrm{ml}$ volumetric flask and diluted with chloroform. A set of reference standard solutions of atropine $(20,40,60,80$, and $100 \mu \mathrm{g} / \mathrm{ml})$ was prepared in the same manner as described earlier. The absorbance for test and standard solutions were determined against the reagent blank at $470 \mathrm{~nm}$ with

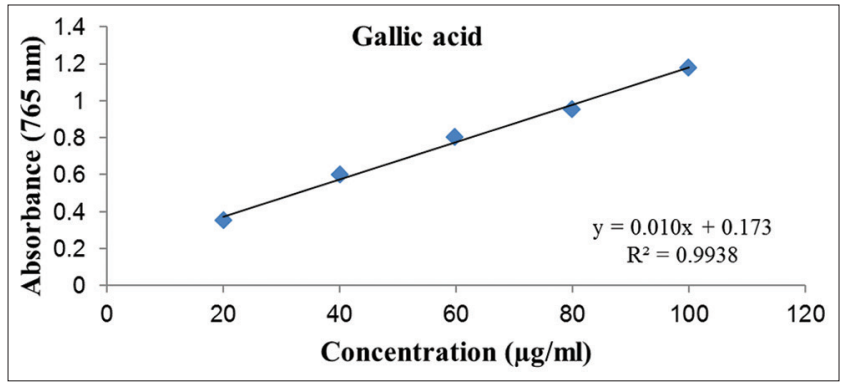

Figure 3: Calibration curve of phenol

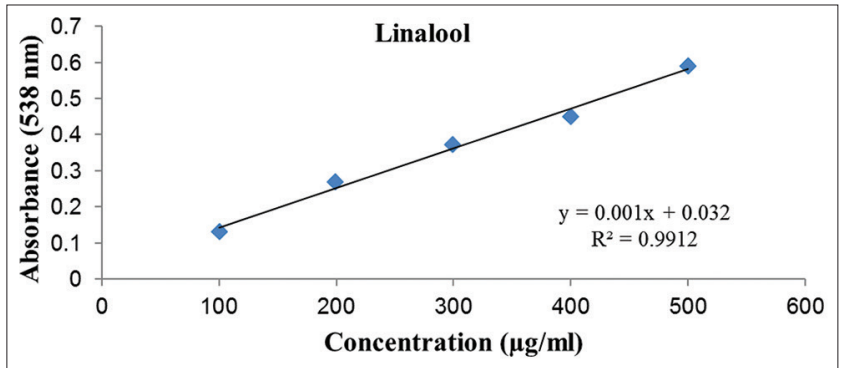

Figure 4: Calibration curve of terpenoids 


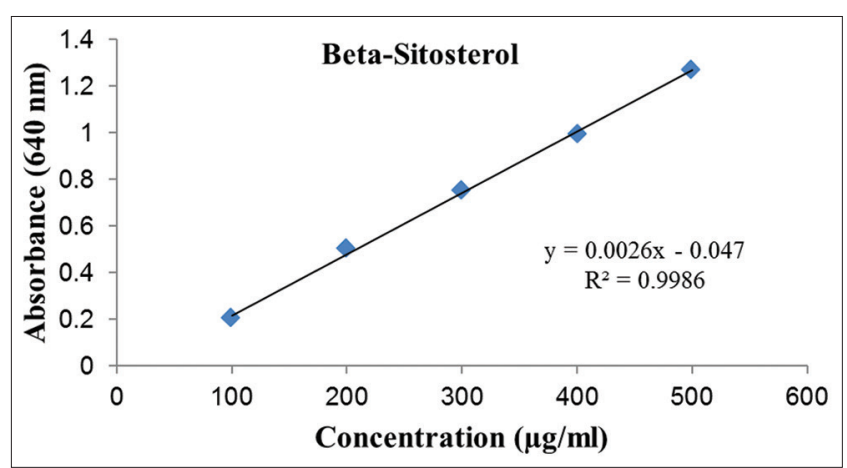

Figure 5: Calibration curve of sterols

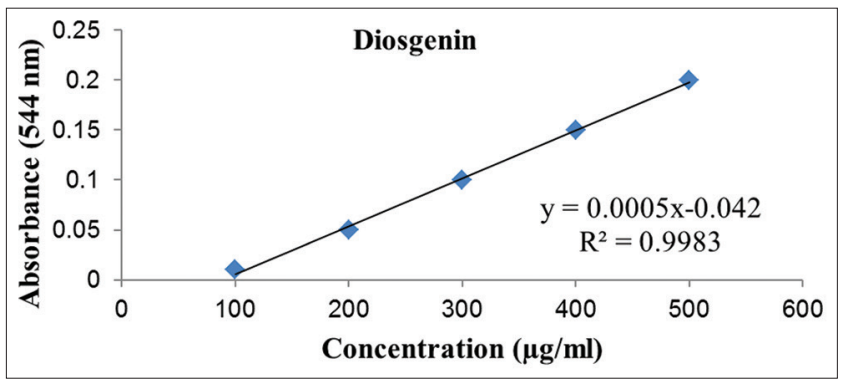

Figure 6: Calibration curve of saponin

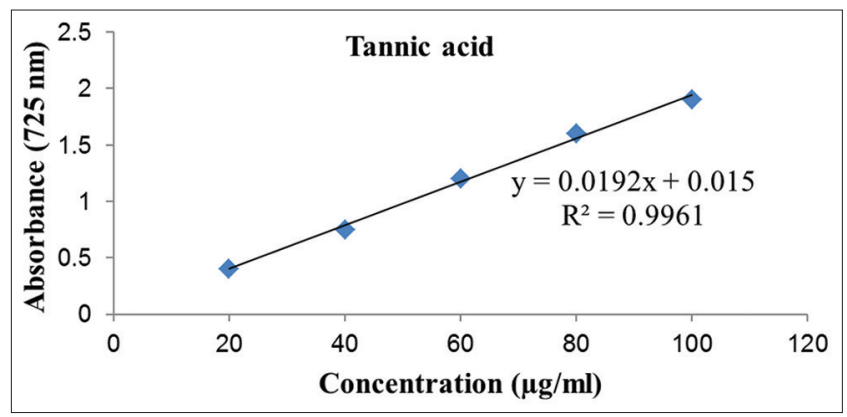

Figure 7: Calibration curve of tannins

an ultraviolet (UV)-Spectrophotometer (SHIMADZU-1800) against the blank.

Absorbance $=0.004$ Atropine $(\mu \mathrm{g} / \mathrm{ml})-0.05\left(r^{2}=0.9907\right)($ Fig. 1).

Quantification was based on the standard curve of atropine. All the tests were carried in triplicates and results were expressed atropine equivalent ( $\mu \mathrm{g}$ of $\mathrm{AE} / \mathrm{mg}$ extracts).

\section{Total flavonoids content}

Total flavonoid content was estimated by a colorimetric method reported by $[17,18]$ with minor modification

Briefly, $0.5 \mathrm{ml}$ of $2 \%$ ethanolic $\mathrm{AlCl}_{3}$ solution was added to $0.5 \mathrm{ml}$ of endophytic fungal crude extract. After $1 \mathrm{~h}$ at room temperature, the absorbance was measured with UV-Spectrophotometers (SHIMADZUUV1800) against the blank at $420 \mathrm{~nm}$. A yellow color indicated the presence of flavonoids. Extracted samples were evaluated at a final concentration of $(1 \mathrm{mg} / \mathrm{ml})$.

Absorbance $=0.005$ Quercetin $(\mu \mathrm{g} / \mathrm{ml})+0.101\left(r^{2}=0.9989\right)$ (Fig. 2).

All the tests were carried out in triplicates and the results were expressed as quercetin equivalent ( $\mu \mathrm{g}$ of quercetin per $\mathrm{mg}$ of extract).

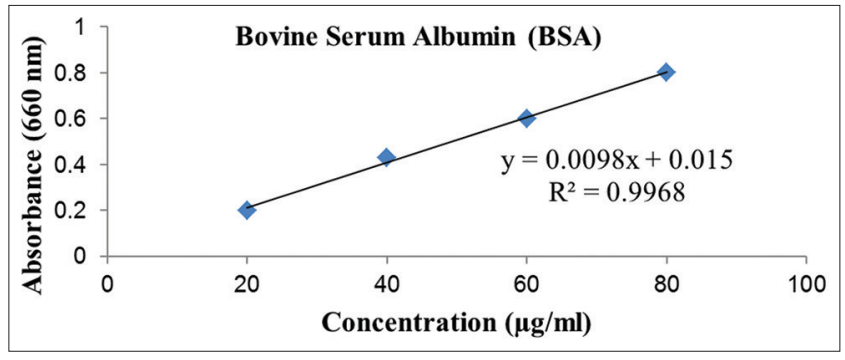

Figure 8: Calibration curve of protein

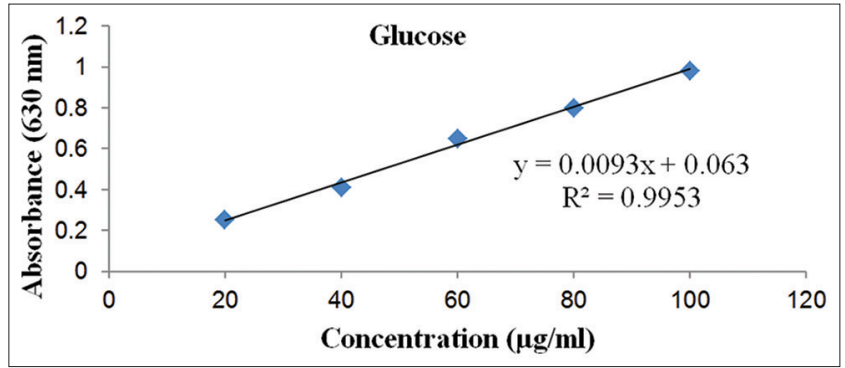

Figure 9: Calibration curve of glucose

Determination of total phenolic content

Total phenolic content was determined by using the Folin-Ciocalteu method $[19,20]$ with minor modification.

Briefly, $0.5 \mathrm{ml}$ of samples $(1 \mathrm{mg} / \mathrm{ml})$ was mixed with $1.8 \mathrm{ml}$ of 10 -fold diluted Folin-Ciocalteu reagent. The mixture was allowed to stand for $5 \mathrm{~min}$ at room temperature and then the reaction was neutralized with $1.2 \mathrm{ml}$ of saturated sodium carbonate (7.5\%). The absorbance of the resulting blue color was measured with a UV-vis spectrophotometer (SHIMADZU UV-1800) against the blank at $765 \mathrm{~nm}$ after incubation for $90 \mathrm{~min}$.

Absorbance $=0.010$ Gallic acid $+0.173\left(r^{2}=0.9938\right)$ (Fig. 3) .

Quantification was based on the standard curve of gallic acid. All the tests were carried in triplicates and results were expressed gallic acid equivalent ( $\mu \mathrm{g}$ of $\mathrm{GAE} / \mathrm{mg}$ extracts).

\section{Estimation of total terpenoids}

Estimation of total terpenoids in the endophytic fungal crude extract was determined by the method of [21] with minor modification.

In the test-tube containing $200 \mu \mathrm{l}$ of endophytic fungal crude extract $(1 \mathrm{mg} / \mathrm{ml}), 1.5 \mathrm{ml}$ of chloroform was added. The sample was vortexed thoroughly and brought to rest for $3 \mathrm{~min}$ and then $100 \mu \mathrm{l}$ of Conc. Sulphuric acid was added to the test-tube and was incubated in room temperature for $1.5-2 \mathrm{~h}$ in the dark. At the end of incubation time, reddish brown precipitation was formed in each assay tubes. All the supernatant were carefully removed from the reaction mixture without disturbing the precipitation. Then, $1.5 \mathrm{ml}$ of $95 \%$ (Vol/Vol) Methanol was added and vortex thoroughly until all the precipitation dissolves in methanol completely. The sample was transferred from assay tube to colorimetric cuvette ( $95 \%$ [Vol/Vol] Methanol was used as blank) to read the absorbance at $538 \mathrm{~nm}$ by using UV-vis spectrophotometer (SHIMADZU UV-1800).

Absorbance $=0.001$ linalool $+0.032\left(r^{2}=0.9912\right)($ Fig. 4).

Quantification was based on the standard curve of linalool. All the tests were carried in triplicates and results were expressed linalool equivalent ( $\mu \mathrm{g}$ of linalool/mg extracts). 

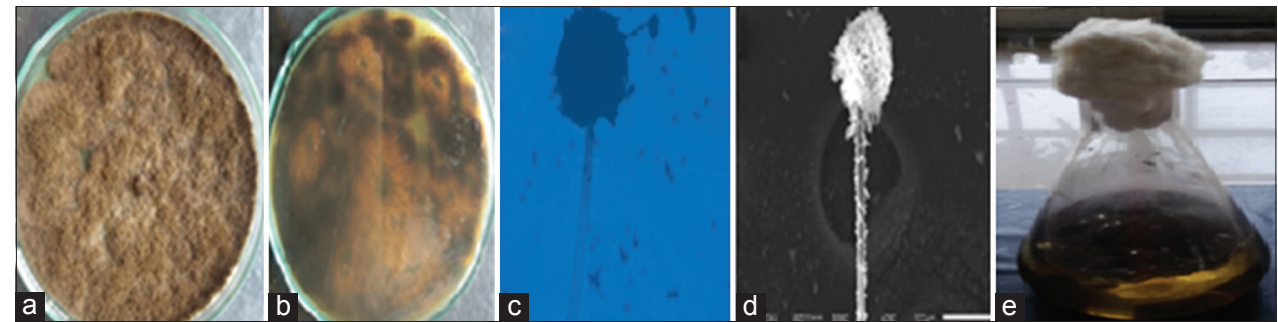

Figure 10: Aspergillus sp.3. (a) Front view in patent ductus arteriosus, (b) reverse view in patent ductus arteriosus, (c) microscopic image, (d) scanning electron microscope image, (e) secondary metabolite production at static condition

\section{Estimation of total sterol}

Estimation of total sterols in the endophytic fungal crude extract was done by the method of [22] with minor modification.

The Liebermann-Burchard (LB) reagent was employed for the quantitative estimation of sterol in the endophytic fungal crude extracts. It was prepared by adding $0.5 \mathrm{ml}$ of concentrated sulfuric acid in $10 \mathrm{ml}$ of acetic anhydride. To $1 \mathrm{ml}$ of each of the extract $(1 \mathrm{mg} / \mathrm{ml})$, chloroform was added to make the volume to $5 \mathrm{ml}$ in a test tube. A volume of $2 \mathrm{ml}$ of LB reagent was added and mixed well. These tubes were then covered with black paper and kept in the dark for 15 min to avoid any exposure to light. The reaction mixture turned green, which was measured spectrophotometrically by using UV-vis spectrophotometer (SHIMADZU UV-1800) at $640 \mathrm{~nm}$ against the blank.

Absorbance $=0.0026$ Beta-Sitosterol $(\mu \mathrm{g} / \mathrm{ml})-0.047\left(r^{2}=0.9986\right)$ (Fig. 5).

Beta-Sitosterol was used as the standard to prepare a calibration curve. All the tests were carried out in triplicates and the results were expressed as Beta-Sitosterol equivalent ( $\mu \mathrm{g}$ of Beta-Sitosterol per mg of extract).

\section{Estimation of total saponin}

Total saponin content was analyzed spectrophotometrically following the method [23] with minor modifications.

Briefly, $1 \mathrm{mg}$ of endophytic fungal crude extract was dissolved in $0.5 \mathrm{ml}$ of $50 \%$ aqueous methanol. $25 \mu \mathrm{l}$ of the aliquot was transferred to test tubes into which an equal volume of vanillin reagent $(8 \%)$ was added followed by $72 \%(\mathrm{v} / \mathrm{v})$ sulfuric acid. The mixture was mixed and placed in a water bath adjusted at $60^{\circ} \mathrm{C}$ for $10 \mathrm{~min}$. The tubes were cooled on an ice-cold water bath for 3 to $4 \mathrm{~min}$, and the absorbance of the yellow color reaction mixture was measured at $544 \mathrm{~nm}$ using a UV-Vis spectrophotometer (SHIMADZU UV-1800) against a blank containing $50 \%$ aqueous ethanol instead of sample extract.

Absorbance $=0.0005$ Diosgenin $(\mu \mathrm{g} / \mathrm{ml})-0.042\left(r^{2}=0.9983\right)($ Fig. 6) .

All the tests were carried out in triplicates and the results were expressed as $\mu$ g Diosgenin equivalents per mg crude extract.

\section{Estimation of total tannins}

The total tannin was determined using the method $[24,25]$ with minor modification.

Briefly, $0.1 \mathrm{ml}$ of extract $(1 \mathrm{mg} / \mathrm{ml}), 6.5 \mathrm{ml}$ of water and $0.5 \mathrm{ml}$ of the Folin-Ciocalteau and $1.5 \mathrm{ml}$ of $20 \%$ sodium carbonate at overnight standard solution were added and incubated at $1 \mathrm{~h}$ the absorbance of the sample was measured in UV-vis spectrophotometer (SHIMADZU UV-1800) against the blank at $725 \mathrm{~nm}$.

Absorbance $=0.0192$ tannic acid $+0.015\left(r^{2}=0.9961\right)$ (Fig. 7).

All the tests were carried out in triplicates and the results were expressed as $\mu \mathrm{g}$ of tannic acid equivalents per mg of extract.

\section{Estimation of total protein}

The total protein content was estimated using the method of [26]. To $1 \mathrm{ml}$ of each test sample, $4 \mathrm{ml}$ of freshly prepared alkaline solution (prepared by mixing $50 \mathrm{ml}$ of $2 \% \mathrm{Na}_{2} \mathrm{CO}_{3}$ in $0.1 \mathrm{~N} \mathrm{NaOH}$ and $1 \mathrm{ml}$ of $0.5 \% \mathrm{CuSO}_{4} \cdot 5 \mathrm{H}_{2} \mathrm{O}$ in $1 \%$ sodium potassium tartrate) was added at room temperature and kept undisturbed for $10 \mathrm{~min}$. Subsequently, to each of these mixtures tubes $0.5 \mathrm{ml}$ of Folin-Ciocalteau reagent was added and after half an hr, the OD of each sample was measured at $660 \mathrm{~nm}$ using UV-vis Spectrophotometer (SHIMADZU UV-1800) against the blank (without protein sample).

Absorbance $=0.0098 \mathrm{BSA}+0.015\left(r^{2}=0.9982\right)($ Fig. 8) .

All the tests were carried out in triplicates, and the results were expressed as $\mu \mathrm{g}$ of protein equivalents per mg of extract.

\section{Estimation of total carbohydrate}

The total carbohydrate content was estimated by the method of [27]. To $1 \mathrm{ml}$ of each sample $4 \mathrm{ml}$ of anthrone reagent $(0.2 \%$ anthrone was dissolved in ice-cold concentrated sulfuric acid, prepared fresh before use) was added, heated for 8 min in boiling water bath, cooled rapidly and the OD of each was measured at $630 \mathrm{~nm}$ using spectrophotometer against the blank (without glucose sample).

Absorbance $=0.0093$ glucose $+0.063\left(r^{2}=0.9953\right)$ (Fig. 9) .

All the tests were carried out in triplicates, and the results were expressed as $\mu$ g of glucose equivalents per mg of extract.

\section{RESULTS}

In the present investigation, the endophytic fungi Aspergillus sp. 3 (Fig. 10). isolated from the B. diffusa L. were analyzed for the presence of qualitative phytochemicals (Table 1) and quantitative phytochemicals (Table 2 and Figs. 1-9).

\section{DISCUSSION}

Medicinal plants are used in traditional medicine system from thousands of years and still continue to give humankind with molecules of therapeutic potentials. Fungal endophytes associated with these plants are also a rich source of novel compounds. Both the medicinal plant and the endophytic fungi are potent sources of natural products. These are also excellent sources of phytochemicals with antioxidant, anti-inflammatory, anticancer, and antimicrobial activity [28].

In the present study, total phenolic, flavonoid, alkaloids, sterols, terpenoids, tannins, etc. content from endophytic fungi isolated from B. diffusa $\mathrm{L}$. were quantified. Total flavonoid content was more when compared to the total phenol content which is similar to the findings of $[29,30]$.

\section{CONCLUSION}

Hence, we conclude that the endophytic fungi isolated from the B. diffusa L. play an important role in discovering and developing new drugs which will be more effective with no side action-like most synthetic drugs. 

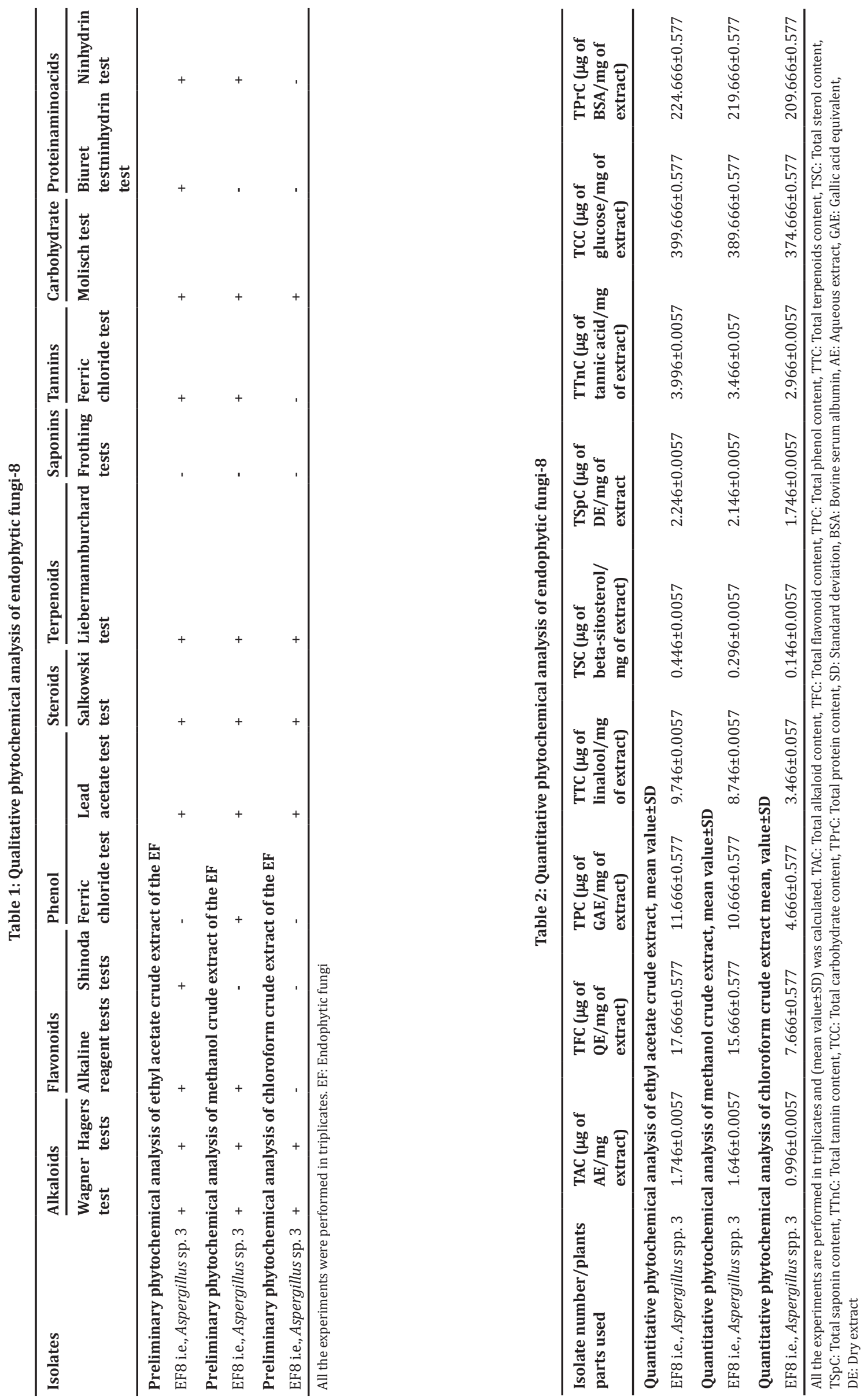


\section{AUTHOR'S CONTRIBUTION}

All the authors contribute equally to the manuscript.

\section{CONFLICT OF INTEREST}

None.

\section{REFERENCES}

1. Singh MK, Usha S, Singh SC, Singh U. Phytoecological investigations of Boerhavia diffusa L. of Darbhanga district, Bihar. Neo-Botan 1994;2:61-4.

2. Jain SP, Singh SC. Ethno Medical Botanical Survey of Ambikapur District, M.P. Ethnobiology in Human Welfare. Lucknow, Uttar Pradesh, India: Abstracts of the $4^{\text {th }}$ International Congress of Ethnobiology; 1994. p. 293

3. Rawat AK, Mehrotra S, Tripathi SK, Shome U. Hepatoprotective activity of Boerhavia diffusa L. roots - A popular Indian ethnomedicine. J Ethnopharmacol 2008;56:61-6.

4. Strobel G, Daisy B. Bioprospecting for microbial endophytes and their natural products. Microbiol Mol Biol Rev 2003;67:491-502.

5. Joseph B, Priya M. Bioactive compounds from endophytes and their potential in pharmaceutical effect: A review. Am J Biochem Mol Biol 2011;1:291-309.

6. Bhardwaj R, Yadav A, Sharma R. Phytochemical and antioxidant activity of Boerhavia diffusa. Int J Pharm Pharm Sci 2014;6:344-8.

7. Pooja VA, Lal VK. Punarnava - A natural remedy by ayurveda. Int $\mathrm{J}$ Pharm Pharm Sci 2014;6:1-6.

8. Fisher PJ, Petrini O. Tissue specificity by fungi endophytic in Ulex europaeus. Sydow 1987;40:46-50.

9. Suryanarayanan TS, Kumaresan V, Johnson JA. Foliar fungal endophytes from two species of the mangrove Rhizophora. Can J Microbiol 1998;44:1003-6.

10. Schulz B, Wanke U, Drager S, Aust HJ. Endophytes from herbaceous plants and shrubs: Effectiveness of surface sterilization methods. Mycol Res 1993;97:1447-50.

11. Buatong J, Phongpaichit S, Rukachaisirikul V, Sakayaroj J. Antimicrobial activity of crude extracts from mangrove fungal endophytes. World J Microbiol Biotechnol 2011;27:3005-8.

12. Kokate CK, Purohit AP, Gokhale SB. Pharmacognosy. Pune, India: Nirali Prakashan; 1997.

13. Kokate CK. Practical Pharmacognosy. New Delhi: Vallabh Prakashan; 2005. p. 107-11

14. Harborne IB. Phytochemical Methods: A Guide to Modern Techniques of Plant Analysis. $3^{\text {rd }}$ ed. London: Chapman and Hall; 1998. p. 302.
15. Manjunath A, Mahadev BG, Shraddha UN. Estimation of total alkaloid in Chitrakadivati by UV-spectrophotometer. Anc Sci Life 2012;31:198-201.

16. Fazel S, Hamidreza M, Rouhollah G, Mohammadreza V. Spectrophotometric determination of total alkaloids in some Iranian medicinal plants. Thai J Pharm Sci 2008;32:17-20.

17. Meda A, Lamien CE, Romito M, Millogo J, Nacoulma OG. Determination of the total phenolic, flavonoid and proline contents in Burkina Fasan honey, as well as their radical scavenging activity. Food Chem 2005:91:571-7.

18. Chang CC, Yang MH, Wen HM, Chern JC. Estimation of total flavonoid content in propolis by two complementary colorimetric methods. J Food Drug Anal 2002;10:178-82.

19. Kim D, Jeong SW, Lee CY. Antioxidant capacity of phenolic phytochemicals from various cultivars of plums. Food Chem 2003;81:321-6.

20. Singleton VL, Rossi JA. Colorimetry of total phenolics with phosphomolybdic-phosphotungstic acid reagents. Am J Enol Viticult 1965;16:144-8.

21. Narayan G, Sondipon C, Shamik G, Samir KS, Suman B. Estimation of Total Terpenoids Concentration in Plant Tissues Using a Monoterpene, Linalool as a Standard Reagent. Protocol Exchange; 2012.

22. Attarde D, Pawar J, Chaudhari B, Pal S. Estimation of sterols content in edible oil and ghee samples. Int J Pharm Sci Rev Res 2010;5:135-7.

23. Hiai S, Oura H, Nakajima T. Color reaction of some sapogenins and saponins with vanillin and sulfuric acid. Planta Med 1976;29:116-22.

24. Polshettiwar SA, Ganjiwale RO, Wadher SJ, Yeole PG. Spectrophotometric estimation of total tannins in some Ayurvedic eye drops. Indian J Pharm Sci 2007;69:574-6

25. Afify AM, El-Beltagi HS, El-Salam SM, Omran AA. Biochemical changes in phenols, flavonoids, tannins, vitamin E, $\beta$-carotene and antioxidant activity during soaking of three white sorghum varieties. Asian Pac J Trop Biomed 2012;2:203-9.

26. Lowry OH, Rosebrough NJ, Farr AL, Randall RJ. Protein measurement with the folin phenol reagent. J Biol Chem 1951;193:265-75.

27. Hedge JE, Hofreiter BT. In: whistler RL, Be Miller JN, editor. Carbohydrate Chemistry. 17 $7^{\text {th }}$ ed. New York: Academic Press; 1962.

28. Cook JB, Dumitru AM, O'Buckley TK, Morrow AL. Ethanol administration produces divergent changes in GABAergic neuroactive steroid immune histochemistry in the rat brain. Alcohol Clin Exp Res 2014;38:90-9.

29. Vijay DT, Rajendra SB. Estimation of total phenol, tannin, alkaloids and flavonoids in Hibiscus tiliaceus L. wood extracts. Res Rev J Pharm Phytochem 2014;2:41-7.

30. Pandita N, Vaidya A. Pharmacognostic and phytochemical studies of Cassia absus seed extracts. Int J Pharm Pharm Sci 2016;8:325-32. 